Wioletta Kilar

Uniwersytet Pedagogiczny

im. Komisji Edukacji Narodowej

w Krakowie

\title{
Zmiany potencjału korporacji informatycznych w Unii Europejskiej w latach 2004-2008
}

W warunkach nasilających się procesów globalizacji i integracji europejskiej ważnym czynnikiem wpływającym na wzrost gospodarczy jest m.in. rozwój systemów informacyjnych i informatycznych oraz zarządzanie wiedzą. Współcześnie należy uznać, że wiedza jest podstawowym zasobem państw, organizacji, instytucji, przedsiębiorstw i poszczególnych osób, który wpływa na ich pozycję konkurencyjną i jest czynnikiem ich szybkiego rozwoju (Borowiec 2008).

$\mathrm{Na}$ obecnym etapie rozwoju społecznego należy przyjąć, że również kształtowanie społeczeństwa informacyjnego, które umożliwia kreowanie gospodarki opartej na wiedzy, jest istotnym czynnikiem umożliwiającym przewagę konkurencyjną (Zioło 2009). Gospodarka taka funkcjonuje kładąc nacisk na „wykorzystanie zasobów wiedzy oraz rozwój technologii umożliwiającej szybki i tani dostęp do informacji, a podstawą jej rozwoju jest zdolność do generowania i dyfuzji innowacji” (Borowiec, Dorocki, Jenner 2009). Proces ten jest możliwy na obszarach dostosowujących różnorodne struktury gospodarcze do zmieniających się uwarunkowań związanych z przechodzeniem od industrialnej poprzez postindustrialną do informacyjnej fazy rozwoju (Rachwał, Wiedermann, Kilar 2009). W zależności od przyjętej polityki, wiele krajów we własnym zakresie dąży do poprawienia ich pozycji konkurencyjnej. W związku z tym, że pozycja Europy w gospodarce światowej, szczególnie w porównaniu ze Stanami Zjednoczonymi, uległa znacznemu osłabieniu, podjęto działania, które mają zmienić tę niekorzystną tendencję. Szefowie państw Unii Europejskiej w 2000 roku podpisali wspólną strategię ekonomiczną i społeczną (Strategię lizbońska), która zakłada, że obszar Unii stanie się najbardziej dynamiczną i konkurencyjną gospodarką na świecie. „Osiagnnięciu tych celów ma służyć m.in. szybkie przechodzenie do gospodarki opartej na wiedzy, rozwój społeczeństwa informacyjnego, badania i zwiększenie innowacyjności gospodarki” (Dorocki 2008).

Należy zaznaczyć, że kształtowanie się informacyjnej fazy rozwoju związane jest z pojawianiem się nowych elementów w strukturze przestrzeni gospodarczej, jakimi są korporacje informatyczne. Procesy kształtowania się korporacji w tej branży obejmują drugą połowę ubiegłego wieku. Genetycznie najstarszą korporacją europejską jest Nokia, założona w 1865 roku jako zakład produkujący papier. W kolejnych latach przekształcała się i zmieniała swój profil produkcji, po czym w latach 80 . ubiegłego stulecia zaczęła produkcję sprzętu elektronicznego (Wajda 2006, www.nokia.pl). Nieco młodsza korporacja, Ericsson, powstała w 1876 roku jako firma początkowo naprawiająca jedynie telegrafy, a następnie produkująca sprzęt elektryczny (m.in. pierwszą na świecie komercyjnie oferowaną maszynę do pisania), wyposażenie telegrafów i opracowanego przez Thomasa A. Edisona pióra elektrycznego. Następnie, 
przekształcając i dostosowując się do potrzeb rynku, zaczęła produkować sprzęt telekomunikacyjny i stała się dostawcą usług i serwisów dla operatorów telekomunikacyjnych na całym świecie (http://alcatel-lucent.com). Zarówno te dwie firmy, jak i wiele innych z tej branży przeprofilowały swoją działalność na informatyczną. Proces ten, a także pojawianie się nowych firm informatycznych w różnej skali układów przestrzennych, można traktować jako wkraczanie ich w informacyjną fazę rozwoju. Wzrost potencjału ekonomicznego korporacji informatycznych oraz nasilające się między nimi powiązania sieciowe w przestrzeni światowej, a także fuzje i przejęcia generują procesy globalizacji i nasilają związane z nimi procesy integracji europejskiej (Zioło 2004, 2009).

W świetle przedstawionych przesłanek w niniejszych rozważaniach podjęta zostanie analiza największych korporacji informatycznych, które mają siedziby zarządów w krajach Unii Europejskiej. Zmierzać będę do określenia zmian ich potencjału ekonomicznego w latach 2004-2008 oraz czynników wpływających na rozmieszczenie przestrzenne korporacji informatycznych w Unii Europejskiej. Dla realizacji założonego przedmiotu i celu wykorzystano cechy określające:

- zmiany potencjału firm informatycznych (liczba firm, wartość majątku i wartość rynkowa),

- zmiany rozmiarów działalności gospodarczej firm (wartość sprzedaży),

- efektywność ich działalności (wynik finansowy),

- korelacje między rodzajem działalności a wynikami korporacji je reprezentującymi.

Podstawową bazę niniejszych rozważań stanowiły dane zaczerpnięte z rankingów Forbes Global 2000 za lata 2004-2008 oraz raporty roczne firm.

Wśród dwóch tysięcy największych korporacji światowych w badanym okresie liczba korporacji informatycznych w Unii Europejskiej ulegała wahaniom i w 2004 roku wynosiła 15, stanowiąc 12,9\% ogółu korporacji informatycznych na świecie, następnie w latach 2005-2006 zmniejszyła się do 14 (około 12\% ogółu korporacji informatycznych). W 2007 roku wzrosła do 16 (11,5\% ogółu), po czym zmalała do 14 (10,6\% ogółu) w 2008 roku (ryc. 1).

Ryc. 1. Zmiany liczby światowych korporacji informatycznych w latach 2004-2008

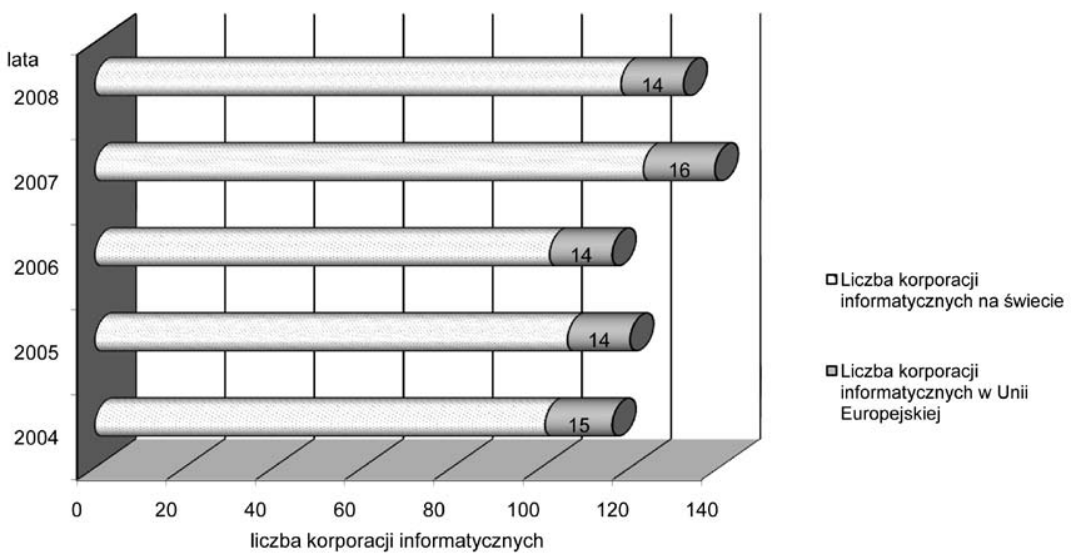

Źródło: opracowanie własne na podstawie The Global 2000 za lata 2004-2008.

Spośród 21 korporacji informatycznych z Unii Europejskiej ujętych w analizowanych rankingach, tylko $10 \mathrm{w}$ tym czasie występowało we wszystkich zestawieniach, natomiast 11 korporacji sporadycznie pojawiało się w strukturze największych światowych firm (np. Marconi, TomTom, Telent, Sagem). Do przedsiębiorstw, które w latach 2004-2008 występowały 
we wszystkich rankingach zaliczamy: Alcatel - Lucent, Amdocs, ASML Holding, Atos Origin, Capgemini, Ericsson, Infineon Technologies, Nokia, SAP i Thomson. Na zmiany liczby korporacji informatycznych $\mathrm{w}$ rankingach $\mathrm{w}$ tym czasie wpłynęły różne czynniki, takie jak przejęcia niektórych korporacji przez inne, np. Marconi została przejęta w 2005 roku przez Ericssona, dlatego jest notowana tylko w 2004 roku, czy Sagem, która od 2005 roku stała się częścią grupy Safran. Niektóre przedsiębiorstwa dopiero powstały w badanym okresie, np. wspomniana korporacja Safran istnieje od 2005 roku, dlatego jest uwzględniana w rankingach dopiero od 2006 r., czy też Telent, która powstała w 2006 roku, wydzielając się z przejmowanej przez Ericssona firmy Marconi. Poza tym zwiększanie się rozmiarów potencjału niektórych firm sprawiło, że pojawiły się one w rankingu, np. TomTom - wiodący dostawca rozwiązań nawigacyjnych na świecie.

Zmiany liczebności europejskich korporacji informatycznych miały pewien wpływ na wielkość skupianego przez nie potencjału ekonomicznego, ogólne wyniki działalności gospodarczej oraz efektywność (tab. 1). Analizowane korporacje charakteryzowały się zróżnicowaną dynamiką potencjału, rozmiarów działalności gospodarczej oraz wyniku finansowego. W latach 2004-2008 najwyższa dynamika zmian wystąpiła w osiaganych wynikach finansowych (profits). Analizowane firmy w 2004 roku łącznie osiagnęły 5,0 mld USD straty, po czym stopniowo wyniki finansowe korporacji zlokalizowanych w Unii Europejskiej zaczęły wzrastać i w 2008 roku osiągnęły razem 14,0 mld USD zysków, czyli w badanym okresie nastapił wzrost do $277,9 \%$.

Tab. 1. Zmiany wartości cech ekonomicznych korporacji informatycznych z Unii Europejskiej w latach 2004-2008

\begin{tabular}{|c|c|c|c|c|c|c|c|}
\hline \multirow{2}{*}{ Lp. } & \multicolumn{5}{|c|}{$\begin{array}{c}\text { Wartość w latach } \\
\text { (w mld USD) }\end{array}$} & $\begin{array}{c}\text { Indeks } \\
\text { dynamiki } \\
\text { w latach } \\
\text { 2004-2008 } \\
\mathbf{2 0 0 4}=\mathbf{1 0 0 \%}\end{array}$ \\
\cline { 3 - 8 } & \multicolumn{2}{|c|}{$\mathbf{2 0 0 4}$} & $\mathbf{2 0 0 5}$ & $\mathbf{2 0 0 6}$ & $\mathbf{2 0 0 7}$ & $\mathbf{2 0 0 8}$ & 183,7 \\
\hline 1 & Aktywa & 131,2 & 140,9 & 140,4 & 179,7 & 241,0 & 107,8 \\
\hline 2 & $\begin{array}{c}\text { Wartość } \\
\text { rynkowa }\end{array}$ & 288,1 & 243,7 & 278,3 & 297,6 & 310,5 & 178,1 \\
\hline 3 & Sprzedaż & 124,2 & 132,7 & 133,5 & 180,5 & 221,1 & 277,9 \\
\hline 4 & $\begin{array}{c}\text { Wyniki } \\
\text { fianansowe } \\
\text { (zysk/strata) }\end{array}$ & $-5,02$ & 10,5 & 11,2 & 16,8 & 14,0 & \\
\hline
\end{tabular}

Źródło: obliczenia własne na podstawie The Global 2000 za lata 2004-2008.

Potencjał ekonomiczny analizowanych korporacji również znacznie się zwiększył. Wartość skupianych aktywów (assets) wzrosła z 131,2 mld USD do 241,0 mld USD, tj. do 183,7\%, a wartość rynkowa (market value) z 288,1 mld USD do 310,5 mld USD, tj. do 107,8\%. Duża dynamika wzrostu nastąpiła również w ogólnej wartości sprzedaży (sales), gdyż zwiększyła się ona z 124,2 mld USD do 221,1 mld USD, tj. do 178,1\% (ryc. 2).

W świetle przedstawionej dynamiki okazuje się, że firmy informatyczne odznaczały się zróżnicowanym tempem w zakresie analizowanych cech. Najwyższe tempo wzrostu zaznacza się w świetle osiąganych zysków, a najniższe - w zakresie wartości rynkowej. Jest to efektem zmienności wpływu koniunktury rynkowej na kształtowanie się rozmiarów produkcji i potencjału ekonomicznego firm. 
Ryc. 2. Zmiany potencjału ekonomicznego, wielkości rozmiarów działalności gospodarczej oraz wyniku finansowego korporacji informatycznych z Unii Europejskiej w latach 2004-2008

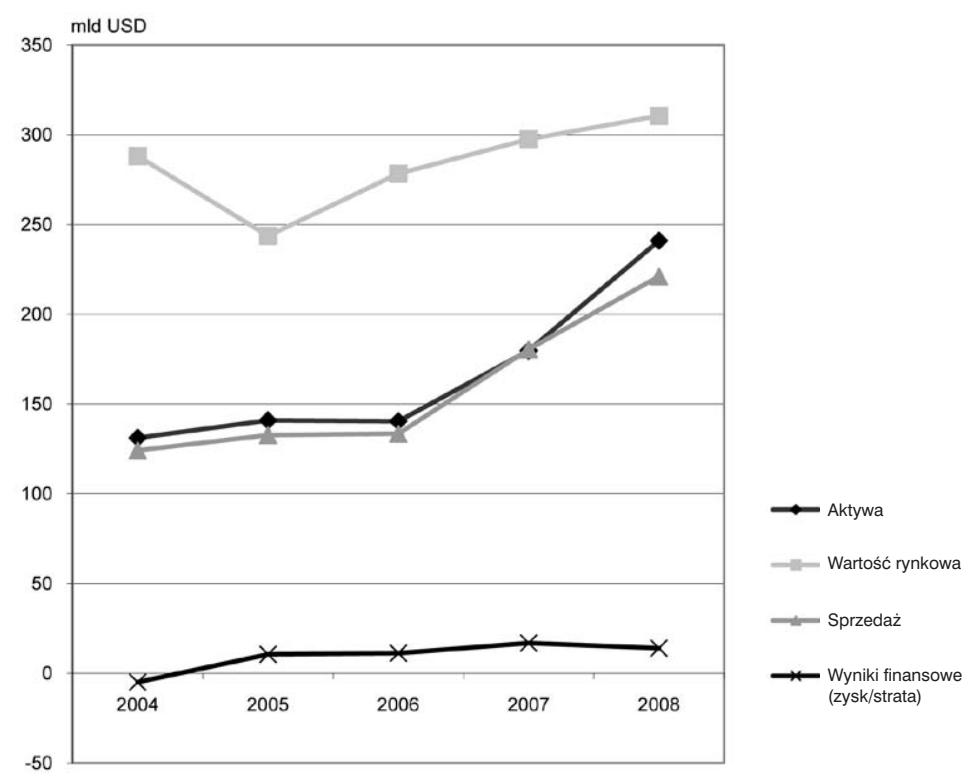

Źródło: opracowanie własne na podstawie The Global 2000 za lata 2004-2008.

W stosunku do ogólnych tendencji przemian poszczególne firmy charakteryzowały się odmiennymi trendami. Potencjał korporacji, określany za pomocą wartości aktywów, wahał się od 0,9 do 52,6 mld USD (tab. 2). W świetle wartości tego miernika dominowały korporacje Nokia, Ericsson i Alcatel-Lucent, których majątek miał wartość od 21,2 do 52,6 mld USD. Najniższą wartością aktywów charakteryzowały się korporacje Dassault Systèmes, TomTom i Telent, których majątek wahał się od 0,9 do 2,8 mld USD. Zróżnicowanie wartości aktywów wynika przede wszystkim z faktu, iż korporacje cechujące się najwyższymi wartościami należą do branży technologie sprzętowe i wyposażenie, i są to firmy o ugruntowanej już pozycji na rynku, zaś Dassault Systèmes zajmuje się oprogramowaniem i usługami, a TomTom i Telent to stosunkowo młode korporacje, które dopiero wypracowują sobie odpowiednie miejsce w reprezentowanych przez siebie branżach.

Analizując dynamikę wartości aktywów widzimy, że najwyższą charakteryzowała się korporacja LogicaCMG, której wartość majątku w latach 2004-2008 wzrosła do 334,87\%, korporację SAP, której aktywa wzrosły do $265,66 \%$, oraz Atos Origin, której majątek zwiększył się do 216,30\% (ryc. 3). Kolejne pozycje zajmują korporacje, które osiagnęły znaczne mniejszą dynamikę aktywów, wynoszącą poniżej 200\%. Na czwartym, piątym, szóstym i siódmym miejscu znajdują się Capgemini, Alcatel-Lucent, Nokia i Ericsson, które osiagnnęły dynamikę na poziomie od 189,71 do 170,65\%, a następnie ASML Holding, Amdocsm i Infineon Technologies, które charakteryzowały się dynamiką od 158,73 do 121,88\%. Natomiast wartość majątku korporacji Thomson w analizowanych latach zmniejszyła się do 99,90\%. Pozostałe korporacje występowały w rankingach sporadycznie, dlatego nie było możliwe określenie dynamiki zmian wartości ich aktywów. 


\begin{tabular}{|c|c|c|c|c|c|c|c|c|c|c|c|c|c|c|c|c|c|c|c|c|c|c|c|c|}
\hline \multirow{5}{*}{ 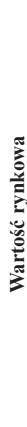 } & 㐫 & $\begin{array}{l}n \\
\hat{g} \\
g\end{array}$ & 学 & 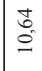 & हे & & $\begin{array}{l}\overrightarrow{0} \\
\infty\end{array}$ & & $\begin{array}{l}n \\
\tilde{n} \\
\dot{m}\end{array}$ & & $\frac{\circ}{6}$ & $\mid \begin{array}{l}2 \\
i\end{array}$ & & 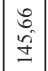 & $\begin{array}{l}\hat{a} \\
\dot{\gamma}\end{array}$ & $\mid$\begin{tabular}{|l}
$\overrightarrow{\omega_{2}}$ \\
$\infty$
\end{tabular} & & & $\begin{array}{l}\text { ․ } \\
\text { in }\end{array}$ & & $\begin{array}{c}8 \\
i \\
i\end{array}$ & $\begin{array}{l}\hat{1} \\
\mathrm{n}^{n}\end{array}$ & $\begin{array}{l}\dot{4} \\
\stackrel{2}{0} \\
m\end{array}$ & \\
\hline & ) & $\begin{array}{l}\text { d̦ } \\
\stackrel{\Delta}{=}\end{array}$ & 곡 & $\stackrel{\Re}{=}$ & $\begin{array}{l}n \\
0 \\
n \\
n\end{array}$ & & $\overrightarrow{\sigma_{2}}$ & & $\begin{array}{l}f \\
f \\
b \\
n\end{array}$ & & 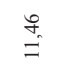 & $\begin{array}{l}\overrightarrow{x_{0}} \\
i\end{array}$ & & $\begin{array}{l}\infty \\
0 \\
0 \\
0 \\
\infty \\
\infty\end{array}$ & $\hat{\hat{\sigma}}$ & 亏े & 莕 & & $\begin{array}{l}\text { I } \\
\infty \\
\text { in }\end{array}$ & $\begin{array}{l}8 \\
:\end{array}$ & $\begin{array}{l}\overrightarrow{\vec{\sigma}} \\
\vec{f}\end{array}$ & $\begin{array}{c} \pm \\
\underset{f}{+}\end{array}$ & $\begin{array}{l}0 \\
n \\
\vdots \\
a\end{array}$ & \\
\hline & : & 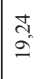 & $\begin{array}{l}5 \\
0 \\
0\end{array}$ & $\stackrel{8}{0}$ & $\stackrel{P}{\stackrel{P}{f}}$ & $\stackrel{2}{=}$ & $\begin{array}{l}8 \\
B_{0}\end{array}$ & $\hat{\beta}_{0}^{n}$ & $\begin{array}{l}g \\
\text { d } \\
\dot{d}\end{array}$ & & \&o & & & $\stackrel{\circ}{\stackrel{0}{\infty}}$ & & $\begin{array}{l}\stackrel{0}{0} \\
\stackrel{0}{\complement}\end{array}$ & $\begin{array}{l}\text { ज } \\
\text { S }\end{array}$ & & $\frac{8}{6}$ & & $\begin{array}{l}\vec{b} \\
+ \\
+\end{array}$ & & 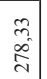 & \\
\hline & 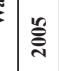 & $\begin{array}{l}\stackrel{8}{二} \\
=\end{array}$ & $\begin{array}{l}\text { gू } \\
\text { in }\end{array}$ & $\begin{array}{l}\hat{\alpha} \\
\infty\end{array}$ & $\begin{array}{l}\infty \\
\infty \\
+\end{array}$ & & $\begin{array}{l}\tilde{g} \\
\dot{f}\end{array}$ & $\begin{array}{l}\infty \\
i \\
i \\
i\end{array}$ & \begin{tabular}{l}
$\infty$ \\
$\infty$ \\
\hdashline \\
\hdashline
\end{tabular} & $\stackrel{\hat{2}}{=}$ & $\underset{\sim}{\alpha_{\infty}}$ & & & $\stackrel{ \pm}{\stackrel{ \pm}{n}}$ & & & $\stackrel{\circ}{\text { in }}$ & $\frac{\partial}{f}$ & $\begin{array}{l}\text { o. } \\
\text { in }\end{array}$ & & ले & & $\begin{array}{l}\infty \\
0 \\
\substack{0 \\
d}\end{array}$ & \\
\hline & ث્̀ & f) & 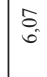 & 寺 & $\mid \begin{array}{l}\infty \\
\infty \\
+\end{array}$ & & ત્ર & $\hat{n}$ & $\begin{array}{l}8 \\
\dot{f} \\
\dot{f}\end{array}$ & & $\stackrel{\Re}{\varrho}$ & $\underset{f}{\stackrel{J}{*}}$ & $\begin{array}{c}\hat{3} \\
i\end{array}$ & $\begin{array}{c}0 \\
0 \\
0 \\
0 \\
=\end{array}$ & & & $\begin{array}{l}\bar{\infty} \\
+ \\
+\end{array}$ & $\begin{array}{l}\vec{y} \\
\text { n' }\end{array}$ & $\stackrel{\circ}{\stackrel{f}{n}}$ & & $\begin{array}{l}t \\
\dot{n} \\
n^{\circ}\end{array}$ & & 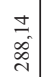 & \\
\hline \multirow{5}{*}{$\frac{\pi}{\tilde{z}}$} & 㐫 & $\begin{array}{l}2 \\
\dot{\gamma} \\
\vec{f}\end{array}$ & $\mid \begin{array}{c}\infty \\
\stackrel{m}{f}\end{array}$ & $\begin{array}{l}m \\
\text { n }\end{array}$ & gु & & $\begin{array}{l}\tilde{2} \\
\stackrel{2}{\varrho}\end{array}$ & & 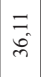 & & $\begin{array}{l}\hat{n} \\
\text { ? }\end{array}$ & $\hat{n}$ & & $\left|\begin{array}{c}0 \\
\text { in } \\
r\end{array}\right|$ & $\stackrel{8}{\circ}$ & 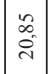 & & & $\begin{array}{l}\Omega \\
\stackrel{\Xi}{\tau}\end{array}$ & & $\stackrel{2}{0}$ & $\begin{array}{c} \pm \\
\infty \\
i \\
i\end{array}$ & $\begin{array}{l}8 \\
\dot{7} \\
\dot{7}\end{array}$ & \\
\hline & ڤิ̀ & \begin{tabular}{|l}
$\infty$ \\
$\tilde{d}$ \\
$\tilde{d}$
\end{tabular} & $\overrightarrow{\tilde{\sigma}}$ & $\begin{array}{l}\stackrel{n}{a} \\
\alpha \\
q\end{array}$ & $\begin{array}{l} \pm \\
\text { a } \\
\text { in }\end{array}$ & & $\begin{array}{c}\tilde{c} \\
\tilde{\infty}_{0}\end{array}$ & & $\begin{array}{l}\vec{F} \\
\text { ì }\end{array}$ & & $\begin{array}{l}\stackrel{q}{9} \\
\stackrel{9}{?}\end{array}$ & $\begin{array}{l}0 \\
0 \\
0\end{array}$ & & 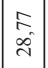 & 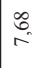 & $\begin{array}{l}0 \\
\infty \\
\infty \\
\infty\end{array}$ & $\begin{array}{l}\vec{a} \\
\text { of }\end{array}$ & & $\begin{array}{l}\underset{+}{J} \\
\text { I }\end{array}$ & E & $\frac{9}{9}$ & $\stackrel{\infty}{=}$ & 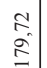 & \\
\hline & نั & 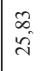 & $\begin{array}{l}0 \\
\text { m } \\
m\end{array}$ & 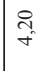 & $\frac{n}{6}$ & $\stackrel{\infty}{\stackrel{-}{-}}$ & $\stackrel{2}{\therefore}$ & $\stackrel{5}{-}$ & $\begin{array}{l}0 \\
\vdots \\
\dot{i}\end{array}$ & & $\stackrel{R}{=}$ & & & 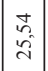 & & $\overrightarrow{m_{j}}$ & $\vec{b}$ & & $\begin{array}{l}\text { ff } \\
\stackrel{9}{=}\end{array}$ & & $\stackrel{i n}{=}$ & & $\begin{array}{l}\bar{f} \\
\dot{q} \\
\dot{q}\end{array}$ & \\
\hline & 䓂 & $\begin{array}{l}\hat{\beta} \\
\hat{n} \\
\hat{\gamma}\end{array}$ & $\begin{array}{l}\infty \\
i \\
\text { in }\end{array}$ & $\stackrel{m}{\rightarrow}$ & $\Rightarrow$ & & 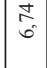 & $\cong$ & $\begin{array}{l}\text { I. } \\
\text { đ̇ }\end{array}$ & ב̂̃ & $\begin{array}{l} \pm \\
\stackrel{+}{\simeq} \\
\simeq\end{array}$ & & & \begin{tabular}{|l|}
$\vec{\partial}$ \\
$\vec{\partial}$
\end{tabular} & & & $\underset{i}{i}$ & $\mid \begin{array}{c}\hat{n} \\
m\end{array}$ & है & & $\begin{array}{l}\hat{\sigma} \\
= \\
=\end{array}$ & & $\begin{array}{c}2 \\
0 \\
0 \\
0\end{array}$ & \\
\hline & 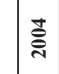 & $\begin{array}{l}\infty \\
0 \\
2 \\
n \\
c\end{array}$ & 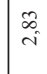 & $\vec{\sigma}$ & $\stackrel{8}{\circ}$ & & \begin{tabular}{c}
\multirow{+}{*}{} \\
in
\end{tabular} & : & $\underset{1}{\stackrel{1}{i}}$ & & $\stackrel{\hat{g}}{=}$ & $\stackrel{\circ}{\approx}$ & $\begin{array}{l}\vec{\sigma} \\
\vec{\sigma}\end{array}$ & $\frac{2}{2}$ & & & $\underset{i}{\Delta}$ & $\begin{array}{l}\infty \\
i \\
i\end{array}$ & is & & 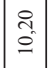 & & $\begin{array}{l}0 \\
\stackrel{0}{-1} \\
\underline{m}\end{array}$ & \\
\hline \multirow{5}{*}{ 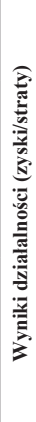 } & 赵 & $\begin{array}{l}\vec{\infty} \\
f \\
f\end{array}$ & के & $\stackrel{8}{-}$ & $\begin{array}{l}n \\
\tilde{n} \\
\hat{q}\end{array}$ & & t. & & $\begin{array}{c}\infty \\
m_{2} \\
n^{2}\end{array}$ & & $\hat{\imath}$ & $\stackrel{0}{\circ}$ & & $\mid \begin{array}{l}\tilde{2} \\
\stackrel{0}{0}\end{array}$ & $\begin{array}{c}\stackrel{2}{2} \\
\hat{q}\end{array}$ & â. & & & 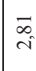 & & $\begin{array}{l}0 \\
0 \\
0\end{array}$ & $\begin{array}{l}0 \\
0 \\
0 \\
0\end{array}$ & $\begin{array}{l}\stackrel{\check{g}}{g} \\
\stackrel{g}{2}\end{array}$ & \\
\hline & 言 & $\stackrel{\varrho}{=}$ & के & $\mid \begin{array}{c}\widetilde{a} \\
\infty \\
0\end{array}$ & $\begin{array}{l}n \\
m \\
\hat{q} \\
\hat{i}\end{array}$ & & $\hat{c}_{0}^{2}$ & & $\begin{array}{l}\tilde{\infty} \\
\tilde{n} \\
\tilde{n}\end{array}$ & & 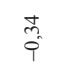 & $\frac{0}{0}$ & & $\begin{array}{l}\infty \\
\dot{0} \\
n^{-1}\end{array}$ & $\begin{array}{l}0 \\
0 \\
0\end{array}$ & กิ & స్ & & 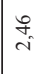 & $\stackrel{+}{\rightarrow}$ & $\begin{array}{ll}0 \\
0 \\
0\end{array}$ & స్ & $\begin{array}{l}\hat{2} \\
\hat{0}\end{array}$ & \\
\hline & : & $\stackrel{\infty}{\stackrel{0}{-}}$ & ते & 角 & $\overrightarrow{\overrightarrow{0}}$ & a & $\stackrel{7}{0}$ & สู & $\underset{\sim}{\mathscr{m}}$ & & 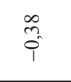 & & & $\begin{array}{l}\hat{\tau} \\
f\end{array}$ & & $\stackrel{\infty}{0}$ & nิ & & F & & $\begin{array}{l}\infty \\
\infty \\
0 \\
0\end{array}$ & & $\stackrel{\infty}{=}$ & \\
\hline & (ั) & $\begin{array}{c}\infty \\
c_{0}^{2}\end{array}$ & $\begin{array}{l}\text { 2ิ } \\
\text { กิ }\end{array}$ & $\tilde{O}_{0}^{2}$ & $\begin{array}{l}\vec{y} \\
\hat{i}\end{array}$ & & $\begin{array}{l}\text { î } \\
\text { की }\end{array}$ & $\overrightarrow{\tilde{O}_{0}}$ & $\begin{array}{l}\stackrel{0}{\infty} \\
i\end{array}$ & $\overline{\hat{\sigma}^{2}}$ & $\stackrel{\infty}{\circ}$ & & & $\begin{array}{l}\stackrel{2}{2} \\
\dot{q}\end{array}$ & & & तิ & $\stackrel{\infty}{0}$ & $\stackrel{\infty}{\simeq}$ & & $\tilde{O}$ & & $\begin{array}{l}\tilde{2} \\
\stackrel{0}{0}\end{array}$ & \\
\hline & ডั̀ & $\begin{array}{l}\infty \\
\infty \\
\dot{f}\end{array}$ & $\frac{9}{0}$ & $\frac{0}{9}$ & : & & $\begin{array}{l}\text { 足 } \\
\text { ô }\end{array}$ & $=$ & $\begin{array}{l}\vec{i} \\
\vec{i}\end{array}$ & & $\begin{array}{l}\vec{n} \\
0 \\
0\end{array}$ & 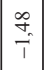 & $\begin{array}{l}\stackrel{0}{7} \\
i\end{array}$ & $\begin{array}{c}\approx \\
\approx \\
+\end{array}$ & & & $\stackrel{0}{0}$ & $\because$ & 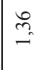 & & $\begin{array}{l}0 \\
0 \\
0\end{array}$ & & $\begin{array}{l}3 \\
-5\end{array}$ & \\
\hline \multirow{5}{*}{ 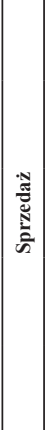 } & \%ั้ & 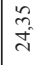 & $\mid \begin{array}{l}\infty \\
i \\
i\end{array}$ & 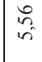 & $\stackrel{ }{\pi}$ & & $\vec{i}$ & & $\begin{array}{l}0 \\
0 \\
0 \\
i\end{array}$ & & 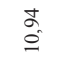 & $\frac{9}{6}$ & & 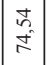 & $\stackrel{2}{2}$ & $\begin{array}{l}1 \\
\\
=\end{array}$ & & & $\begin{array}{l}\stackrel{\circ}{ \pm} \\
\stackrel{+}{ \pm}\end{array}$ & & $\stackrel{2}{\stackrel{2}{\sim}}$ & 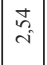 & $\begin{array}{l}\stackrel{2}{\vec{i}} \\
\vec{i}\end{array}$ & \\
\hline & ثิ & $\begin{array}{l}\hat{n} \\
\hat{n} \\
-1\end{array}$ & $\mid \begin{array}{l}\infty \\
n \\
n \\
n\end{array}$ & $\begin{array}{l}n \\
\dot{q}\end{array}$ & $\stackrel{\simeq}{\therefore}$ & & $\begin{array}{l}\stackrel{0}{0} \\
\stackrel{0}{0}\end{array}$ & & $\begin{array}{l}\text { aे } \\
\text { cે }\end{array}$ & & $\begin{array}{l}\circ \\
\stackrel{0}{\circ}\end{array}$ & $\begin{array}{l}\tilde{A} \\
n^{2}\end{array}$ & & 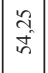 & $\begin{array}{c}5 \\
\text { in }\end{array}$ & $\begin{array}{l}2 \\
2 \\
\pm \\
\dot{y}\end{array}$ & $\stackrel{n}{=}$ & & $\begin{array}{l}\stackrel{9}{\mathfrak{I}} \\
\text { I }\end{array}$ & 点 & $\cong$ & $\underset{\substack{\infty \\
-}}{\stackrel{\infty}{*}}$ & 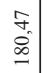 & \\
\hline & 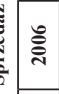 & $\begin{array}{l}n \\
n \\
n\end{array}$ & $\stackrel{4}{\stackrel{4}{0}}$ & बे & $\frac{\partial}{n}$ & $\stackrel{n}{-1}$ & $\begin{array}{l}\tilde{\pi} \\
\infty\end{array}$ & $\cong$ & $\begin{array}{l}\stackrel{0}{\circ} \\
\stackrel{0}{2}\end{array}$ & & $\stackrel{\simeq}{\infty}$ & & & $\begin{array}{l}\vec{F} \\
\dot{q}\end{array}$ & & 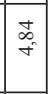 & $\hat{\sim}$ & & $\stackrel{8}{\varrho}$ & & \begin{tabular}{|l|} 
\\
$\infty$ \\
$\varrho$ \\
$\varrho$
\end{tabular} & & 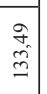 & \\
\hline & 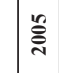 & $\begin{array}{l}\text { ț } \\
\text { - }\end{array}$ & $\vec{\infty}$ & $\begin{array}{c}m \\
m \\
m\end{array}$ & $\mid \begin{array}{l}\alpha \\
\infty \\
\sim \\
\tilde{c}\end{array}$ & & 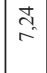 & $\stackrel{\infty}{\circ}$ & $\begin{array}{l}\infty \\
\infty \\
\stackrel{0}{=}\end{array}$ & $\begin{array}{l}0 \\
m \\
m \\
m\end{array}$ & $\begin{array}{l}\text { r. } \\
\text { no }\end{array}$ & & & \begin{tabular}{|l}
$\vec{n}$ \\
$\hat{m}$
\end{tabular} & & & $\stackrel{\sim}{\cong}$ & 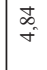 & $\begin{array}{l}\text { त्र } \\
\text { S }\end{array}$ & & $\begin{array}{l}\mathbb{0} \\
\stackrel{0}{0} \\
\subseteq\end{array}$ & & $\begin{array}{l}0 \\
0 \\
i \\
-1\end{array}$ & \\
\hline & ডั & $\begin{array}{l}\infty \\
\stackrel{\infty}{=} \\
=\end{array}$ & $\stackrel{n}{n}$ & $\stackrel{ \pm}{\rightarrow}$ & \begin{tabular}{|c|}
$\vec{\infty}$ \\
$\tilde{r}$
\end{tabular} & & 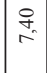 & $\begin{array}{l}\vec{\infty} \\
0 \\
0\end{array}$ & $\begin{array}{l}\stackrel{\partial}{0} \\
\underline{\leftrightarrow}\end{array}$ & & $\stackrel{\infty}{\sim}$ & 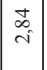 & $\begin{array}{l}8 \\
m\end{array}$ & $\mid \begin{array}{l}2 \\
\therefore \\
\tilde{m}\end{array}$ & & & g. & $\begin{array}{l}8 \\
+\end{array}$ & $\begin{array}{l} \pm \\
\infty \\
\infty\end{array}$ & & $\begin{array}{l}\mathbf{J} \\
\stackrel{0}{0}\end{array}$ & & $\begin{array}{l}\infty \\
\stackrel{ \pm}{ \pm} \\
\mathbb{I}\end{array}$ & \\
\hline & 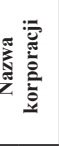 & 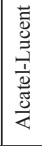 & 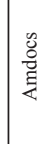 & 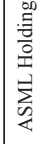 & 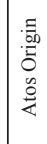 & $\overline{\bar{\Xi}}$ & 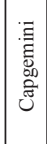 & 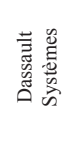 & 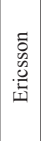 & 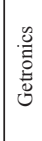 & 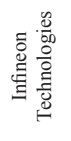 & 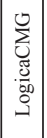 & 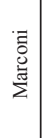 & $\frac{\frac{\pi}{4}}{\dot{0}}$ & 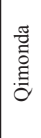 & 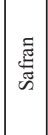 & 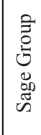 & 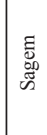 & 离 & 䓂 & 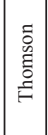 & 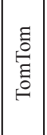 & \multirow[t]{2}{*}{$\begin{array}{l}\text { : } \\
\text { 善 } \\
\text { o }\end{array}$} & $\begin{array}{l}\frac{1}{0} \\
\text { N } \\
\text { 응 } \\
0 \\
0\end{array}$ \\
\hline & $\dot{3}$ & - & N & $m$ & + & in & 0 & $r$ & $\infty$ & a & $\subseteq$ & $=$ & $\simeq$ & $\cong$ & \pm & $\cong$ & $\stackrel{\bullet}{0}$ & $=$ & $\stackrel{\infty}{.}$ & 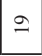 & ন & $\vec{\sim}$ & & \\
\hline
\end{tabular}


Ryc. 3. Zmiany wartości aktywów korporacji informatycznych z Unii Europejskiej w latach 2004-2008

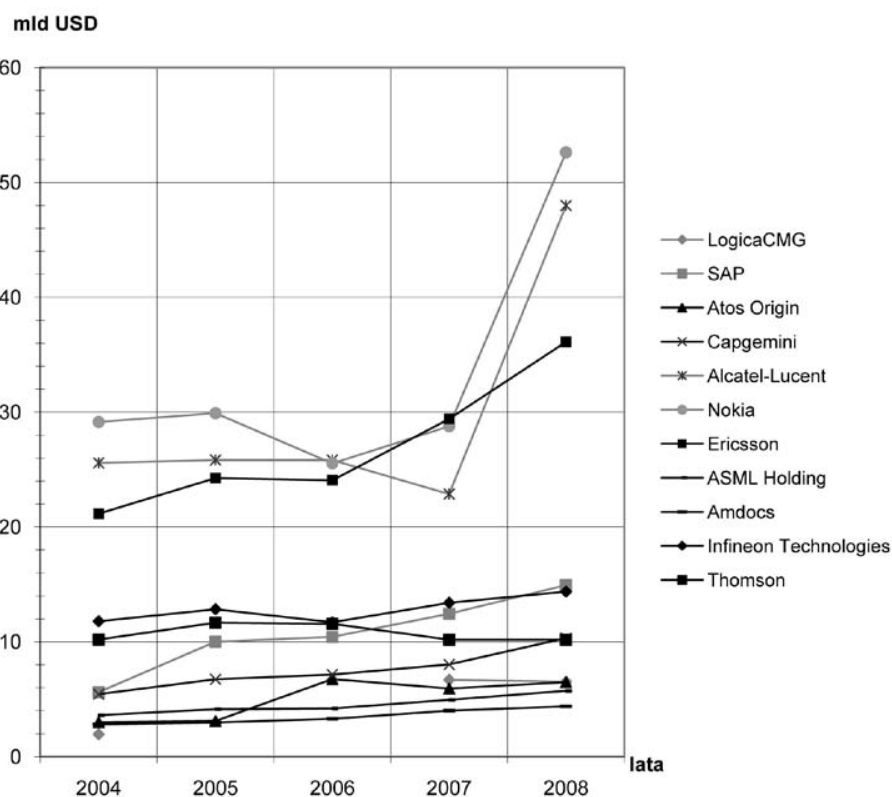

Źródło: opracowanie własne na podstawie The Global 2000 za lata 2004-2008.

Kolejną cechą określającą potencjał ekonomiczny badanych firm jest ich wartość rynkowa. W analizowanym okresie miernik ten wahał się od 0,60 do 145,66 mld USD. Najwyższą wartość rynkową we wszystkich latach posiadała korporacja Nokia i wahała się ona od 73,14 do 145,66 mld USD, a na drugim i trzecim miejscu plasowały się firmy SAP i Ericsson, których wartości znajdowały się w przedziale od 34,53 do 63,10 mld USD. Najniższa wartość rynkowa cechowała korporacje Telent, Bull i Getronics i wynosiła ona od 0,60 do 1,33 mld USD. Należy podkreślić, że większość korporacji posiadała w badanym okresie wartość rynkową do 20 mld, a jedynie wspomniane: Nokia, Ericsson i SAP miały wartość znacznie ponad ten pułap.

Natomiast dokonując analizy dynamiki tego miernika należy zauważyć, że połowa firm w latach 2004-2008 osiaggnęła wzrost wartości rynkowej, zaś druga część zanotowała jej spadek. Najwyższa dynamika charakteryzowała korporację Nokia, której wartość wzrosła do 139,7\% (tab. 3). Na drugiej pozycji znajduje się Capgemini, której indeks dynamiki wyniósł w badanych latach 127,8\%, a na trzeciej ASML Holding która cechowała się wzrostem wartości rynkowej do $112,7 \%$. W grupie państw, w których również odnotowano wzrost tego indeksu były SAP i Amdocs i wynosił on odpowiednio 106,8 do 106,3\%. W kolejnych 6 korporacjach, tj. w firmie Ericsson, Atos Origin, Alcatel-Lucent, LogicaCMG, Infineon Technologies i Thomson wartość rynkowa zmniejszyła się do poziomu od 78,4 do 36,4\% w stosunku do 2004 roku.

Rozpatrując rozmiary działalności korporacji informatycznych, określanej za pomocą analizy wartości sprzedaży, należy zaznaczyć, że wahała się ona od 0,54 do 74,54 mld USD. Najwyższą wartością tego miernika, podobnie jak w przypadku wartości aktywów i wartości rynkowej, odznaczała się firma Nokia, która w latach 2004-2008 odnotowywała stały, systematyczny wzrost wartości sprzedaży z 37,05 do 74,54 mld USD. Znacznie mniejsze wpływy z tej działalności, ale jednak plasując się w czołówce, osiagnęły korporacje Alcatel-Lucent 
Tab. 3. Zmiany wartości rynkowej korporacji informatycznych z Unii Europejskiej w latach 2004-2008

\begin{tabular}{|c|c|c|c|c|c|c|c|}
\hline \multirow{2}{*}{ Lp. } & \multirow{2}{*}{$\begin{array}{c}\text { Nazwa } \\
\text { korporacji }\end{array}$} & \multicolumn{5}{|c|}{ Wartość rynkowa w mld USD } & \multirow{2}{*}{$\begin{array}{c}\text { Dynamika } \\
\text { wartości } \\
\text { rynkowej } \\
2004= \\
100 \%\end{array}$} \\
\hline & & 2004 & 2005 & 2006 & 2007 & 2008 & \\
\hline 1 & Nokia & 104,30 & 73,14 & 78,10 & 86,38 & 145,66 & 139,7 \\
\hline 2 & Capgemini & 6,27 & 4,93 & 6,50 & 9,21 & 8,01 & 127,8 \\
\hline 3 & $\begin{array}{c}\text { ASML } \\
\text { Holding }\end{array}$ & 9,44 & 8,97 & 10,06 & 11,73 & 10,64 & 112,7 \\
\hline 4 & SAP & 54,10 & 50,69 & 63,10 & 58,26 & 57,77 & 106,8 \\
\hline 5 & Amdocs & 6,07 & 5,93 & 6,67 & 7,20 & 6,45 & 106,3 \\
\hline 6 & Ericsson & 44,06 & 46,86 & 54,09 & 56,47 & 34,53 & 78,4 \\
\hline 7 & Atos Origin & 4,86 & 4,89 & 4,70 & 3,65 & 3,79 & 78,0 \\
\hline 8 & $\begin{array}{l}\text { Alcatel- } \\
\text {-Lucent }\end{array}$ & 20,43 & 17,06 & 19,24 & 18,24 & 13,75 & 67,3 \\
\hline 9 & LogicaCMG & 4,14 & & & 3,81 & 2,70 & 65,2 \\
\hline 10 & $\begin{array}{c}\text { Infineon } \\
\text { Technologies }\end{array}$ & 10,73 & 7,82 & 6,90 & 11,46 & 6,10 & 56,8 \\
\hline 11 & Thomson & 5,74 & 7,39 & 4,61 & 4,91 & 2,09 & 36,4 \\
\hline & Ogółem & 270,14 & 227,68 & 253,97 & 271,32 & 291,49 & 107,9 \\
\hline
\end{tabular}

Źródło: obliczenia własne na podstawie The Global 2000 za lata 2004-2008.

i Ericsson, których sprzedaż wynosiła od 15,53 do 29,05 mld USD. Natomiast najmniejszą wartością sprzedaży charakteryzowały się takie korporacje jak Telent, Dassault Systèmes i Sage Group, które cechowały się wartością tego miernika na poziomie od 0,54 do 1,75 mld USD. Pozostałe firmy w badanym okresie odznaczały się zbliżonymi wartościami sprzedaży, oscylującymi wokół 10 mld USD.

W świetle przeprowadzonej analizy największą dynamiką wartości sprzedaży odznaczała się firma ASML Holding, która zwiększyła sprzedaż do 286,6\% (tab. 4). Kolejne pozycje zajmują LogicaCMG, Nokia, Atos Origin i Amdocs, których dynamika sprzedaży wahała się od 184,1 do 214,8\%. Znacznie mniejszą dynamika, od 140,1 do 173,0\% charakteryzowały się Ericsson, Capgemini, SAP, Infineon Technologies i Alcatel - Lucent. Natomiast korporacja Thomson zmniejszyła sprzedaż do 72,6\% wartości w stosunku do 2004 roku. Zmienność wartości sprzedaży może być wyrazem m.in. zmniejszania pozycji konkurencyjnej produktów oferowanych przez omawiane korporacje.

Analizując efektywność działalności prowadzonej przez 21 europejskich korporacji, które przyjęto do badań należy zaznaczyć, że wartość ich wyników finansowych wahała się od -4,98 do 10,52 mld USD. Również pod tym względem znacznie ponad pozostałe korporacje wybijała się Nokia, gdyż jej zyski wahały się od 4,27 mld USD do 10,52 mld USD (ryc. 4). Stosunkowo dużymi zyskami cechowała się także firma Ericsson, której wyniki działalności wzrastały od -2,19 do 3,83 mld USD. Natomiast najsłabsze wyniki charakteryzowały firmę Alcatel-Lucent, która w latach 2004-2008 była na granicy zysku lub osiagała straty, gdyż jej wynik finansowy wynosił od -4,98 do 1,10 mld USD. 
Tab. 4. Zmiany wartości sprzedaży (obrotów) korporacji informatycznych z Unii Europejskiej w latach 2004-2008

\begin{tabular}{|c|c|c|c|c|c|c|c|}
\hline \multirow{2}{*}{ Lp. } & \multirow{2}{*}{$\begin{array}{c}\text { Nazwa } \\
\text { korporacji }\end{array}$} & \multicolumn{5}{|c|}{ Sprzedaż (w mld USD) } & \multirow{2}{*}{$\begin{array}{c}\text { Dynamika } \\
\text { wartości } \\
\text { sprzedaży } \\
2004=100 \%\end{array}$} \\
\hline & & 2004 & 2005 & 2006 & 2007 & 2008 & \\
\hline 1 & ASML Holding & 1,94 & 3,35 & 2,99 & 4,75 & 5,56 & 286,6 \\
\hline 2 & LogicaCMG & 2,84 & & & 5,22 & 6,10 & 214,8 \\
\hline 3 & Nokia & 37,05 & 39,71 & 40,41 & 54,25 & 74,54 & 201,2 \\
\hline 4 & Atos Origin & 3,81 & 3,82 & 7,19 & 7,12 & 7,12 & 186,9 \\
\hline 5 & Amdocs & 1,57 & 1,81 & 2,16 & 2,58 & 2,89 & 184,1 \\
\hline 6 & Ericsson & 16,79 & 19,86 & 19,08 & 25,97 & 29,05 & 173,0 \\
\hline 7 & Capgemini & 7,40 & 7,24 & 8,22 & 10,16 & 12,71 & 171,8 \\
\hline 8 & SAP & 8,84 & 10,20 & 10,06 & 12,40 & 14,96 & 169,2 \\
\hline 9 & $\begin{array}{c}\text { Infineon } \\
\text { Technologies }\end{array}$ & 7,18 & 8,95 & 8,12 & 10,06 & 10,94 & 152,4 \\
\hline 10 & Alcatel-Lucent & 17,38 & 16,64 & 15,53 & 15,53 & 24,35 & 140,1 \\
\hline 11 & Thomson & 10,64 & 10,64 & 10,85 & 7,72 & 7,72 & 72,6 \\
\hline \multicolumn{2}{|r|}{ Ogółem } & 115,44 & 122,22 & 124,61 & 155,76 & 195,94 & 169,7 \\
\hline
\end{tabular}

Źródło: obliczenia własne na podstawie The Global 2000 za lata 2004-2008.

Najwyższą dynamiką efektywności w badanym okresie charakteryzowały się korporacje Nokia i SAP, które osiągnęły wyniki odpowiednio 232,7\% i 206,6\%. Znaczną dynamiką odznaczały się również korporacje Amdocs i Thomson, których zyski wzrosły w kolejności do 194,7\% i 166,7\%. Natomiast dynamika efektywności korporacji Infineon Technologies i Alcatel-Lucent w tym okresie wyniosła odpowiednio 102,0\% i 96,6\%.

Ryc. 4. Zmiany wartości wyniku finansowego korporacji informatycznych z Unii Europejskiej w latach 2004-2008

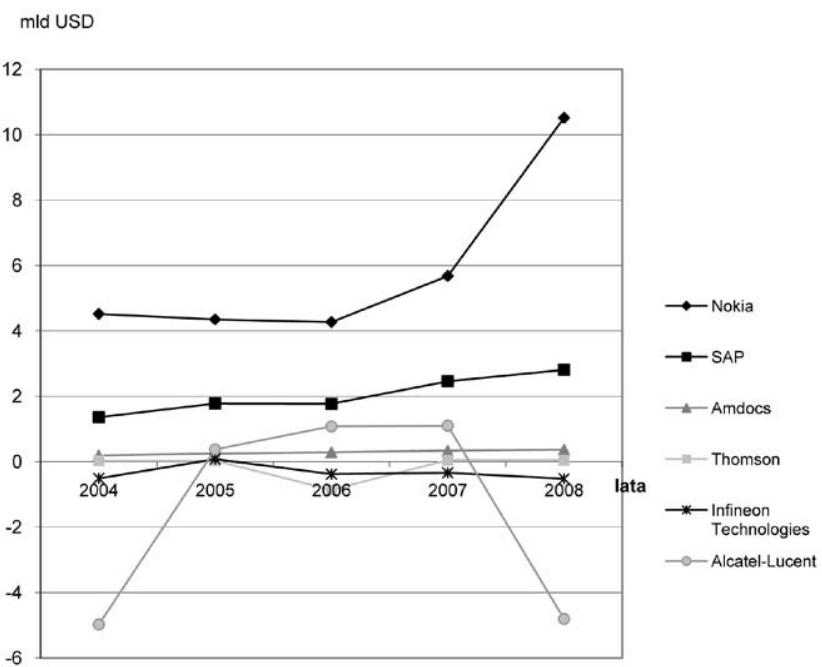

Źródło: opracowanie własne na podstawie The Global 2000 za lata 2004-2008. 
„Przestrzeń światowa stwarza bardzo zróżnicowane warunki dla lokalizacji zarządów nowoczesnych firm związanych z informacyjną fazą rozwoju społecznego. Oznacza to działanie procesów polaryzacji, które prowadzą do zróżnicowania przestrzennego liczebności siedzib korporacji, a także ich potencjału ekonomicznego" (Kilar 2009). Procesy polaryzacji lokalizacji zarządów korporacji informatycznych mają miejsce również na obszarze Unii Europejskiej, gdyż analizowane korporacje koncentrowały siedziby zarządów firm na terenie jedynie 6 krajów Unii Europejskiej (ryc. 5). Najwięcej, bo 8 z 21 badanych korporacji ma swoje siedziby we Francji. Dogodne warunki dla korporacji informatycznych występują również w Wielkiej Brytanii, w której swoje siedziby ma 5 spośród badanych firm, a także w Niemczech i Niderlandach, w których są zlokalizowane po 3 korporacje. Natomiast w Finlandii i Szwecji jest zlokalizowanych po 1 korporacji. Istnieje wiele przyczyn tak dużej polaryzacji przestrzeni Unii Europejskiej pod tym względem. Istotnym powodem jest przyjmowana przez rozwinięte ekonomicznie kraje polityka, która zakłada, że wielkie nakłady przeznacza się w nich na prace badawczo-rozwojowe, co sprawia, że kraje te dążą do zbudowania w nich gospodarki opartej na wiedzy. Niepokojącym jest fakt, iż żadna z korporacji informatycznych ujętych w rankingach nie ma swojej siedziby w krajach Europy południowej i środkowo-wschodniej, czego przyczyn należy szukać m.in. w historii tych obszarów oraz w stopniu ich rozwoju gospodarczego.

Ryc. 5. Liczba siedzib zarządów korporacji informatycznych w latach 2004-2008 wg państw

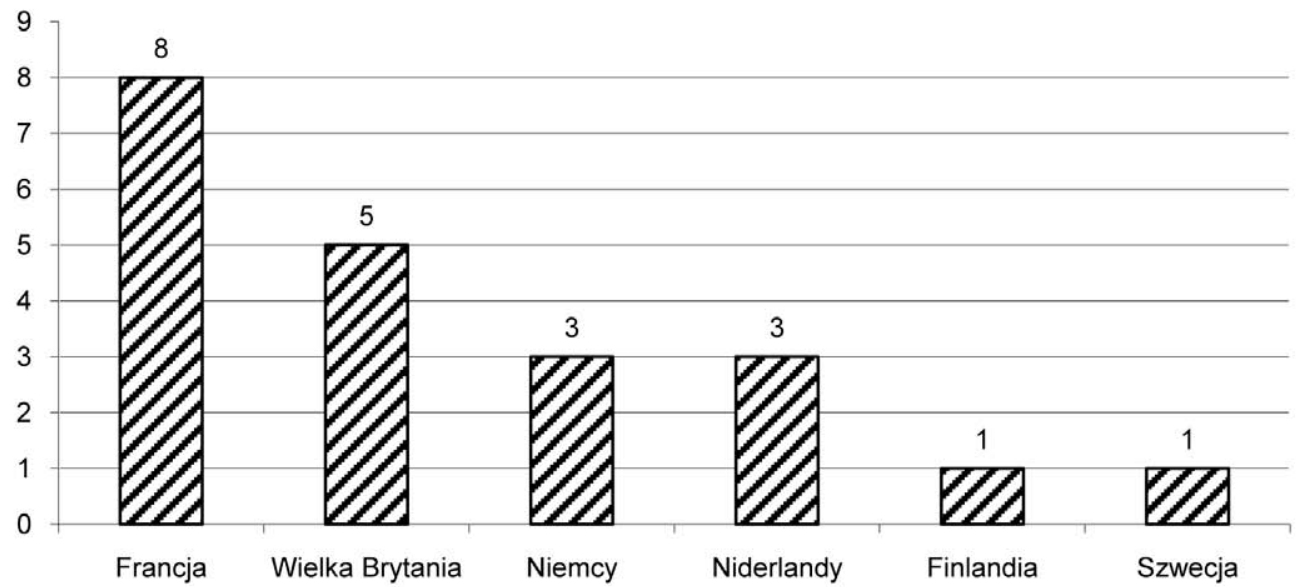

Źródło: opracowanie własne na podstawie The Global 2000 za lata 2004-2008.

Kraje, w których zlokalizowano siedziby zarządów badanych firm charakteryzują się zróżnicowanym potencjałem ekonomicznym korporacji skupiających się na ich terenie, który ulegał w badanym okresie pewnym wahaniom. Biorąc pod uwagę zróżnicowanie wartości aktywów badanych korporacji wg państw, zauważa się dominację wartości majątku korporacji, których siedziby znajdują się we Francji i Finlandii (ryc. 6). W 2004 roku aktywa firm z Francji wynosiły 48,1 mld USD, a w 2008 roku 95,8 mld USD, stanowiąc odpowiednio $36,7 \%$ i 39,8\%. Natomiast korporacja fińska (Nokia) stanowiła w 2004 roku 22,2\%, a w 2008 roku $21,8 \%$ ogółu wartości majątku badanych korporacji. W pozostałych państwach skupiało się w 2004 roku 41,1\% ogółu wartości aktywów, a w 2008 roku 38,4\% ogółu tej wartości. 
Ryc. 6. Struktura wartości aktywów korporacji informatycznych z Unii Europejskiej w 2004 i 2008 roku wg państw
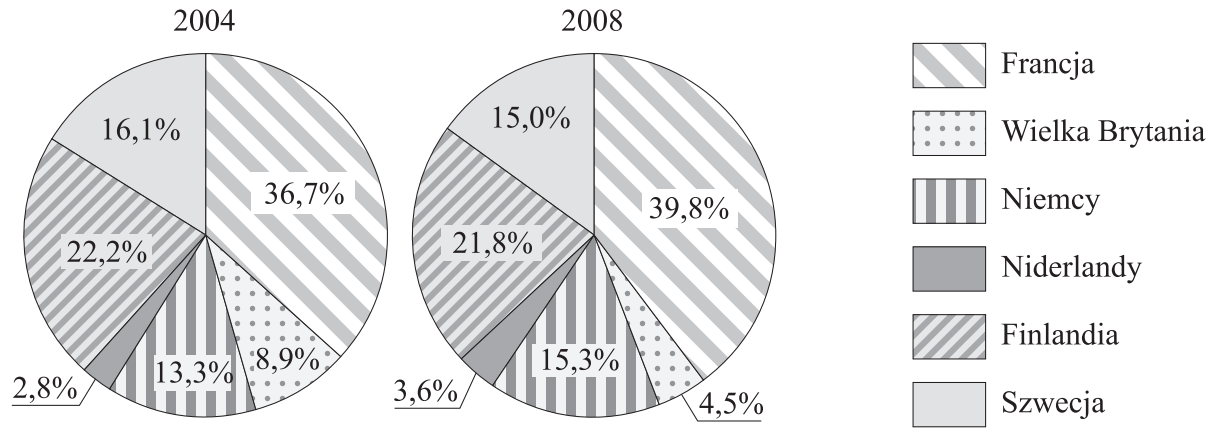

Źródło: opracowanie własne na podstawie The Global 2000 za lata 2004-2008.

Natomiast potencjał ekonomiczny mierzony wartością rynkową firm skupia się w Finlandii, w której koncentrowało się 36,2\% wartości rynkowej ogółu korporacji w 2004 roku i 46,9\% w 2008 roku (ryc. 7). Uwzględniając ten miernik w strukturze wyróżniają się również korporacje zlokalizowane w Niemczech, gdyż łączna ich wartość rynkowa w 2004 roku stanowiła 22,5\% ogółu, a w 2008 roku 22,2\%. Pozostałe państwa skupiały korporacje odznaczające się łącznie w 2004 roku 41,3\% udziału w ogóle, a w 2008 roku 30,9\%.

Ryc. 7. Struktura wartości rynkowej korporacji informatycznych z Unii Europejskiej w 2004 i 2008 roku wg państw
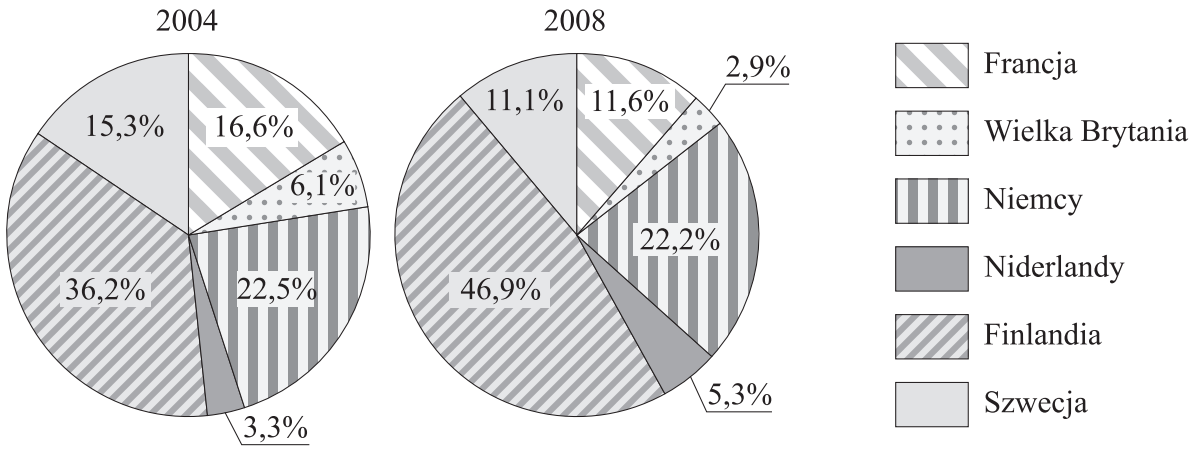

Źródło: opracowanie własne na podstawie The Global 2000 za lata 2004-2008.

Analizując rozmiary działalności określane wartością sprzedaży, wyróżniają się w obydwu przedziałach czasowych korporacje, które mają siedziby swoich zarządów we Francji i Finlandii (ryc. 8). W 2004 roku korporacje francuskie koncentrowały 35,5\% ogółu sprzedaży, a w 2008 roku 31,4\% ogółu, zaś korporacja fińska w 2004 roku skupiała 29,8\%, a w 2008 roku $33,7 \%$ ogółu obrotów. W pozostałych państwach osiągnięto łącznie 34,7\% ogółu sprzedaży w 2004 roku i 34,9\% w 2008 roku. 
Ryc. 8. Struktura wartości sprzedaży korporacji informatycznych z Unii Europejskiej w 2004 i 2008 roku wg państw
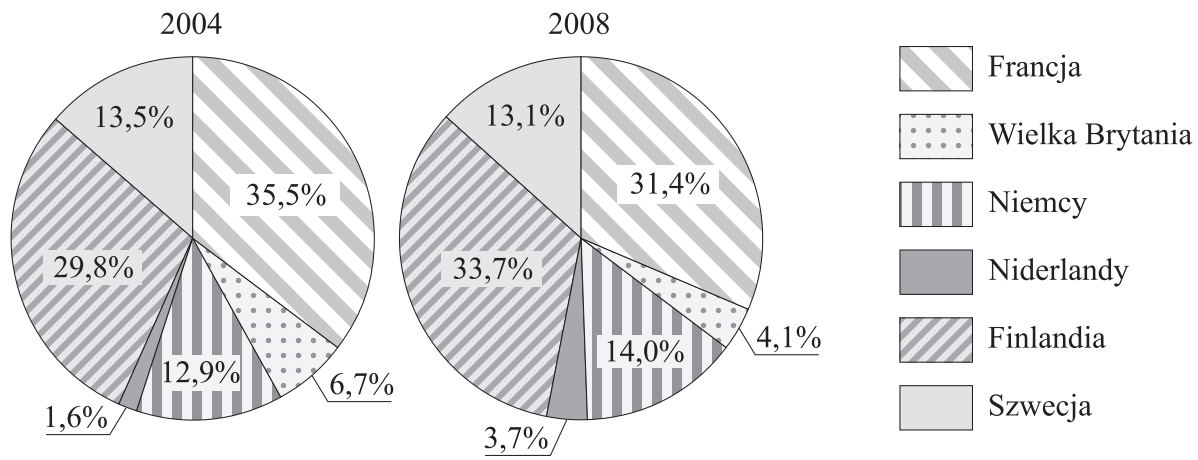

Źródło: opracowanie własne na podstawie The Global 2000 za lata 2004-2008.

Dokonując analizy efektywności działalności badanych korporacji w latach 2004-2008 zauważa się stosunkowo duże zmiany w strukturze Unii Europejskiej (ryc. 9). W 2004 roku wypracowane przez europejskie korporacje zyski rozkładały się dość równomiernie w przestrzeni, przy czym korporacje posiadające siedziby zarządów we Francji i Finlandii stanowiły odpowiednio po 32,7\% i 28,7\% ogółu. Natomiast w 2008 roku 48,5\% ogółu zysków skupiała korporacja fińska, a francuskie firmy łącznie obejmowały jedynie 17,9\% ogółu. Korporacje zlokalizowane w pozostałych państwach skupiały łącznie 38,6\% ogółu zysków w 2004 roku i $33,7 \%$ w roku 2008 .

Ryc. 9. Struktura wyników finansowych korporacji informatycznych z Unii Europejskiej w 2004 i 2008 roku wg państw
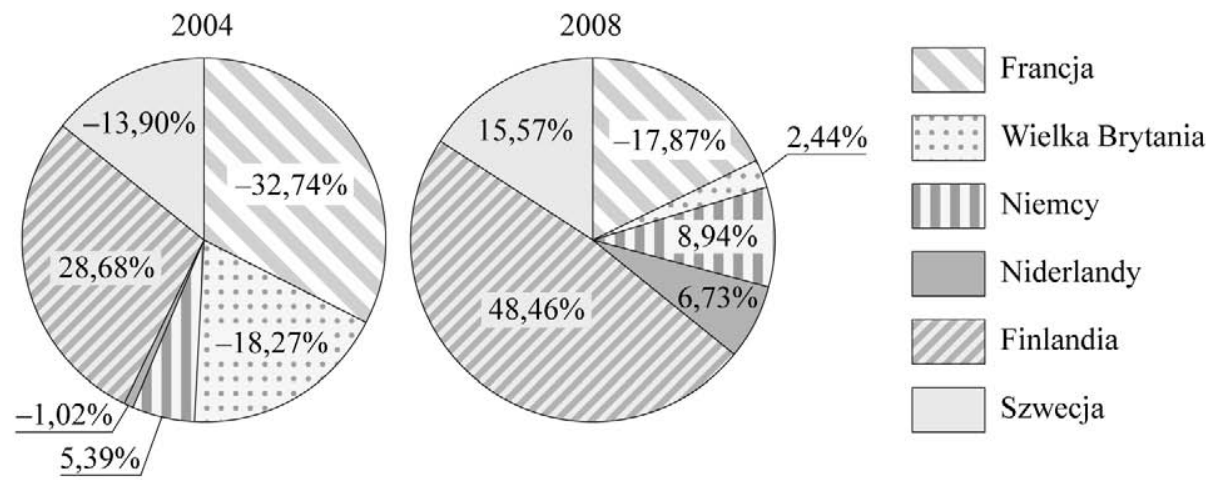

Źródło: opracowanie własne na podstawie The Global 2000 za lata 2004-2008.

Podsumowując, w badanym okresie zaznacza się znaczne zróżnicowanie struktury wartości skupianego potencjału ekonomicznego, wielkości rozmiarów działalności gospodarczej oraz wyniku finansowego korporacji informatycznych z Unii Europejskiej wg państw. Biorąc pod uwagę dynamikę zmian wartości omawianych cech wg państw, szczególnie wyróżniają się Niderlandy, z których korporacje wygenerowały wzrost sprzedaży do 417,5\%, wartości majątku do $237,4 \%$ oraz wartości rynkowej do $173,8 \%$ (ryc. 10). Natomiast niepokojące zmiany 
nastąpiły w korporacjach, których siedziby zarządów mieszczą się w Wielkiej Brytanii, gdyż co prawda łączna ich sprzedaż wzrosła do 107,8\%, lecz wartość aktywów zmniejszyła się do 93,0\%, a ich wartość rynkowa do 51,8\%, co może świadczyć o słabnącej ich pozycji na rynku.

Ryc. 10. Zmiany wartości skupianego potencjału ekonomicznego, wielkości rozmiarów działalności gospodarczej oraz wyniku finansowego korporacji informatycznych z Unii Europejskiej

w latach 2004-2008 wg państw

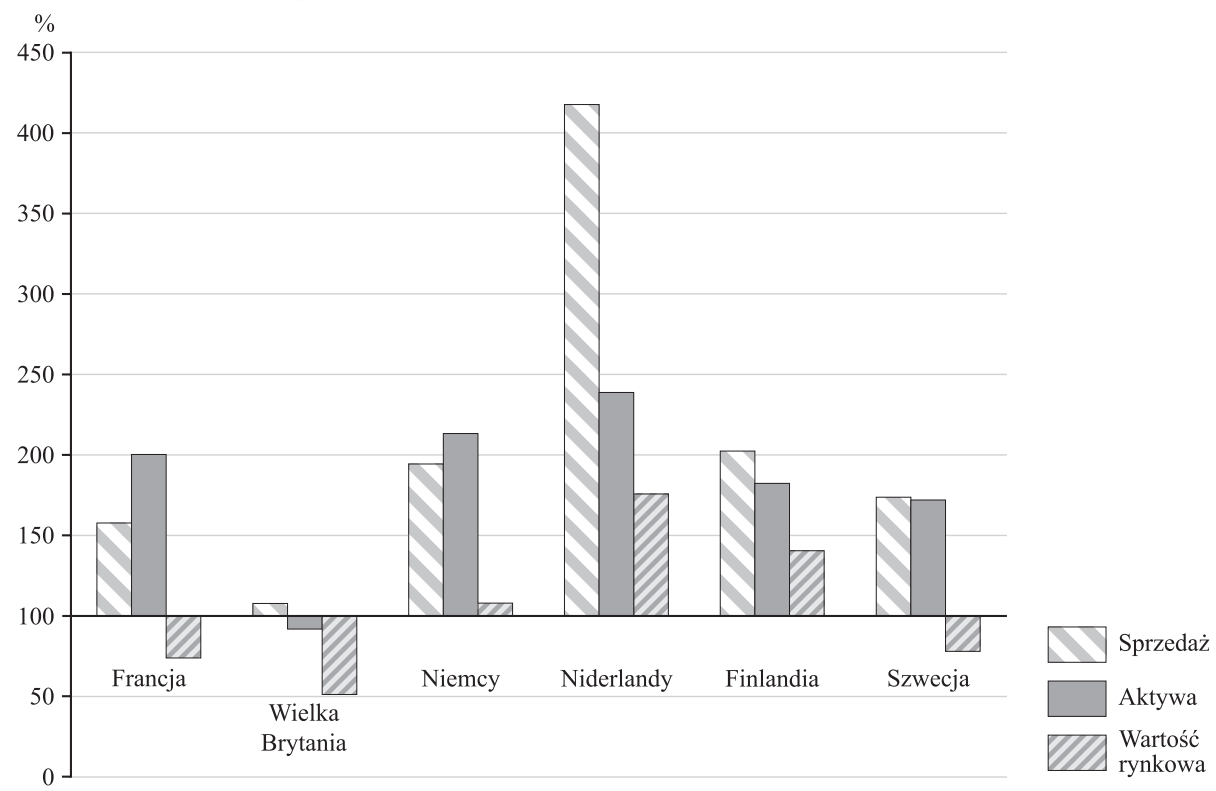

Źródło: opracowanie własne na podstawie The Global 2000 za lata 2004-2008.

Biorąc pod uwagę zróżnicowanie działalności prowadzonej przez analizowane korporacje, wyróżnia się 3 rodzaje działalności: oprogramowanie i usługi, półprzewodniki oraz technologie sprzętowe i wyposażenie. Generalnie uwzględniając liczbę korporacji, które reprezentują te działalności, to istotne znaczenie w strukturze podejmowanej działalności ma grupa 9 korporacji reprezentująca kategorię oprogramowanie i usługi oraz 10 firm, które zaklasyfikowane są do technologii sprzętowych i wyposażenia. Natomiast półprzewodniki to rodzaj działalności, którym zajmują się jedynie dwie z badanych korporacji informatycznych.

Analizując strukturę działalności korporacji informatycznych z Unii Europejskiej, dominujące znaczenie mają korporacje reprezentujące technologie sprzętowe i wyposażenie, które łącznie wygenerowały we wszystkich latach od $62,6 \%$ do $71,7 \%$ ogółu aktywów, od 60,3\% do $67,7 \%$ ogółu wartości rynkowej, od $66,9 \%$ do $71,6 \%$ ogółu sprzedaży i od 73,1\% do 84,3\% ogółu zysków (tab. 5).

W latach 2004-2008 nastąpiły kilkuprocentowe zmiany udziałów poszczególnych rodzajów działalności w strukturze wybranych cech. W tym czasie jedynie struktura wyników finansowych znacznie się zmieniła, gdyż udział technologii sprzętowych i wyposażenia zmniejszył się z 84,3\% w 2004 roku do 64,9\% w 2008 roku oraz grupy półprzewodniki z 10,2\% do 5,5\%, wzrosło zaś znaczenie grupy oprogramowanie i usługi z 5,6\% do 29,5\% (ryc. 11). Można więc zauważyć, że znacznie rośnie efektywność korporacji, których profilem działalności jest oprogramowanie i usługi, co może wynikać zarówno ze wzrostu zapotrzebowania na nie i silnej ich specjalizacji (niektóre z badanych firm świadczą m.in. usługi outsourcingowe). 
Tab. 5. Rodzaje działalności korporacji informatycznych z Unii Europejskiej w latach 2004-2008

\begin{tabular}{|c|c|c|c|c|c|c|c|c|c|}
\hline \multirow[b]{2}{*}{ Lp. } & \multirow[b]{2}{*}{ Cechy } & \multirow[b]{2}{*}{ Lata } & \multicolumn{3}{|c|}{$\begin{array}{l}\text { Wyniki działalności } \\
\text { (w miliardach USD) }\end{array}$} & \multirow[b]{2}{*}{ Ogółem } & \multicolumn{3}{|c|}{ Struktura (w \%) } \\
\hline & & & 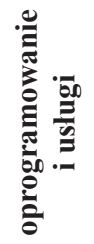 & 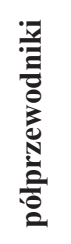 & 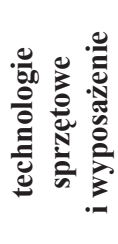 & & 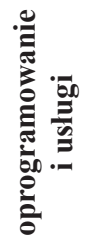 & 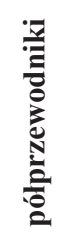 & 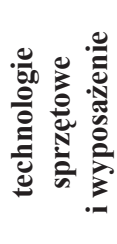 \\
\hline \multirow{5}{*}{1} & \multirow{5}{*}{ Sprzedaż } & 2004 & 28,1 & 7,2 & 88,9 & 124,2 & 22,7 & 5,8 & 71,6 \\
\hline & & 2005 & 32,1 & 9,0 & 91,7 & 132,7 & 24,2 & 6,7 & 69,1 \\
\hline & & 2006 & 33,1 & 8,1 & 92,3 & 133,5 & 24,8 & 6,1 & 69,1 \\
\hline & & 2007 & 44,0 & 15,7 & 120,8 & 180,5 & 24,4 & 8,7 & 66,9 \\
\hline & & 2008 & 49,3 & 16,1 & 155,7 & 221,1 & 22,3 & 7,3 & 70,4 \\
\hline \multirow{5}{*}{2} & \multirow{5}{*}{ Zyski } & 2004 & 0,3 & $-0,5$ & $-4,2$ & $-5,0$ & 5,6 & 10,2 & 84,3 \\
\hline & & 2005 & 2,6 & 0,1 & 7,8 & 10,5 & 25,1 & 0,8 & 74,1 \\
\hline & & 2006 & 3,1 & $-0,4$ & 8,5 & 11,2 & 27,5 & $-3,4$ & 75,8 \\
\hline & & 2007 & 4,1 & 0,2 & 12,5 & 16,8 & 24,5 & 1,0 & 74,6 \\
\hline & & 2008 & 4,6 & $-0,9$ & 10,2 & 14,0 & 33,2 & $-6,2$ & 73,0 \\
\hline \multirow{5}{*}{3} & \multirow{5}{*}{ Aktywa } & 2004 & 25,4 & 11,8 & 94,0 & 131,2 & 19,4 & 9,0 & 71,7 \\
\hline & & 2005 & 32,8 & 12,8 & 95,2 & 140,9 & 23,3 & 9,1 & 67,6 \\
\hline & & 2006 & 36,1 & 11,7 & 92,6 & 140,4 & 25,7 & 8,3 & 65,9 \\
\hline & & 2007 & 46,2 & 21,1 & 112,5 & 179,7 & 25,7 & 11,7 & 62,6 \\
\hline & & 2008 & 48,4 & 22,0 & 170,6 & 241,0 & 20,1 & 9,1 & 70,8 \\
\hline \multirow{5}{*}{4} & \multirow{5}{*}{$\begin{array}{l}\text { Wartość } \\
\text { rynkowa }\end{array}$} & 2004 & 95,0 & 10,7 & 182,4 & 288,1 & 33,0 & 3,7 & 63,3 \\
\hline & & 2005 & 87,2 & 7,8 & 148,6 & 243,7 & 35,8 & 3,2 & 61,0 \\
\hline & & 2006 & 103,6 & 6,9 & 167,8 & 278,3 & 37,2 & 2,5 & 60,3 \\
\hline & & 2007 & 100,4 & 16,4 & 180,7 & 297,6 & 33,7 & 5,5 & 60,7 \\
\hline & & 2008 & 89,4 & 11,1 & 210,1 & 310,5 & 28,8 & 3,6 & 67,7 \\
\hline
\end{tabular}

Źródło: obliczenia własne na podstawie The Global 2000 za lata 2004-2008.

Ryc. 11. Struktura wyników finansowych korporacji informatycznych z Unii Europejskiej w 2004 i 2008 roku wg rodzajów działalności

2004

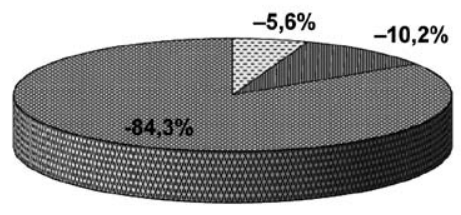

2008

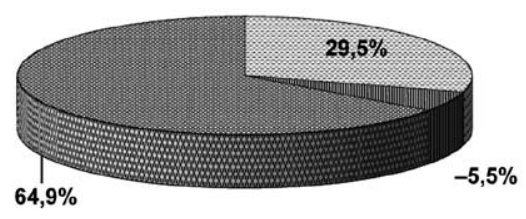

Doprogramowanie i usługi

mpółprzewodniki

هtechnologie sprzętowe i wyposażenie

Źródło: opracowanie własne na podstawie The Global 2000 za lata 2004-2008. 
Analizowane korporacje charakteryzują się zróżnicowaną korelacją między poszczególnymi cechami je charakteryzującymi (tab. 6). Istotna zależność statystyczna (umiarkowana korelacja) występuje między ogólną wartością aktywów korporacji informatycznych a wartością osiąganych wyników finansowych. Wysoka korelacja występuje między wartością sprzedaży a wartością ich wyników finansowych, wartością wyników finansowych a wartością rynkową korporacji oraz wartością rynkową a wartością posiadanych aktywów. Natomiast bardzo duża zależność statystyczna (bardzo wysoka korelacja) ma miejsce między wartością sprzedaży a wartością posiadanego majątku oraz wartością rynkową.

Tab. 6. Współczynnik korelacji między cechami korporacji informatycznych z Unii Europejskiej za lata 2004-2008

\begin{tabular}{|c|c|c|c|c|}
\hline Cechy & $\begin{array}{c}\text { wartość } \\
\text { sprzedaży }\end{array}$ & $\begin{array}{c}\text { wartość } \\
\text { zysków } \\
\text { i strat }\end{array}$ & $\begin{array}{c}\text { wartość } \\
\text { aktywów }\end{array}$ & $\begin{array}{c}\text { wartość } \\
\text { rynkowa }\end{array}$ \\
\hline $\begin{array}{c}\text { wartość } \\
\text { sprzedaży }\end{array}$ & 1,000 & 1,000 & & \\
\hline $\begin{array}{c}\text { wartośćc } \\
\text { zysków } \\
\text { i strat }\end{array}$ & 0,705 & 0,432 & 1,000 & \\
\hline $\begin{array}{c}\text { wartość } \\
\text { aktywów }\end{array}$ & 0,879 & 0,795 & 0,694 & 1,000 \\
\hline $\begin{array}{c}\text { wartośćc } \\
\text { rynkowa }\end{array}$ & 0,863 & & \\
\hline
\end{tabular}

Źródło: obliczenia własne na podstawie The Global 2000 za lata 2004-2008.

Jednakże istnieje pewne zróżnicowanie współczynnika korelacji między poszczególnymi cechami w zależności od rodzajów podejmowanych działalności przez omawiane korporacje (tab. 7). Praktycznie nie występuje związek (słaba korelacja) między wartością osiąganych wyników finansowych a wartością rynkową korporacji reprezentujących oprogramowanie i usługi oraz technologie sprzętowe i wyposażenie, a także między wartością aktywów a wartością rynkową korporacji zajmujących się oprogramowaniem i usługami. Zauważalna jest również niemalże pełna zależność statystyczna we wszystkich rodzajach działalności między wartością sprzedaży a wartością posiadanego majątku, a w przypadku korporacji należących do grupy oprogramowanie i usługi również między wartością majątku a wartością osiaganych wyników finansowych. W trzech przypadkach zależności, między:

- wartością sprzedaży a wartością zysków w przypadku firm zajmujących się półprzewodnikami,

- wartością sprzedaży a wartością rynkową w przypadku firm z grupy oprogramowanie i usługi,

- wartością wyników finansowych a wartością posiadanego majątku w przypadku korporacji z grupy półprzewodniki,

- zauważalna jest korelacja ujemna, która informuje, że wzrostowi wartości jednej cechy towarzyszy spadek średnich wartości drugiej cechy. 
Tab. 7. Współczynnik korelacji między cechami korporacji informatycznych z Unii Europejskiej za lata 2004-2008 wg rodzajów działalności

\begin{tabular}{|c|c|c|c|c|}
\hline Cechy & $\begin{array}{c}\text { wartość } \\
\text { sprzedaży }\end{array}$ & $\begin{array}{c}\text { wartość } \\
\text { zysków }\end{array}$ & $\begin{array}{c}\text { wartość } \\
\text { aktywów }\end{array}$ & $\begin{array}{c}\text { wartość } \\
\text { rynkowa }\end{array}$ \\
\hline \multicolumn{5}{|c|}{ oprogramowanie i usługi } \\
\hline $\begin{array}{c}\text { wartość } \\
\text { sprzedaży }\end{array}$ & 1,000 & & & \\
\hline $\begin{array}{c}\text { wartość } \\
\text { zysków }\end{array}$ & 0,859 & 1,000 & & \\
\hline $\begin{array}{c}\text { wartość } \\
\text { aktywów }\end{array}$ & 0,970 & 0,944 & 1,000 & \\
\hline $\begin{array}{c}\text { wartość } \\
\text { rynkowa }\end{array}$ & 0,110 & 0,005 & 0,034 & 1,000 \\
\hline \multicolumn{2}{|c|}{ pólprzewodniki } & \\
\hline $\begin{array}{c}\text { wartość } \\
\text { sprzedaży }\end{array}$ & 1,000 & & & \\
\hline $\begin{array}{c}\text { wartość } \\
\text { zysków }\end{array}$ & $-0,062$ & 1,000 & & 1,000 \\
\hline $\begin{array}{c}\text { wartość } \\
\text { aktywów }\end{array}$ & 0,995 & $-0,120$ & 1,000 & \\
\hline $\begin{array}{c}\text { wartość } \\
\text { rynkowa }\end{array}$ & 0,710 & 0,255 & 0,729 & \\
\hline \multicolumn{1}{|c|}{ technologie sprzętowe i wyposażenie } \\
\hline $\begin{array}{c}\text { wartość } \\
\text { sprzedaży }\end{array}$ & 1,000 & & & \\
\hline $\begin{array}{c}\text { wartość } \\
\text { zysków }\end{array}$ & 0,537 & 1,000 & \\
\hline $\begin{array}{c}\text { wartość } \\
\text { aktywów }\end{array}$ & 0,974 & 0,405 & 1,000 & \\
\hline $\begin{array}{c}\text { wartość } \\
\text { rynkowa }\end{array}$ & 0,821 & 0,051 & 0,835 & \\
\hline Zno: & & \\
\hline
\end{tabular}

Źródło: obliczenia własne na podstawie The Global 2000 za lata 2004-2008.

Podsumowując, należy przyjąć, że analizowane korporacje informatyczne odznaczają się bardzo zróżnicowanymi tendencjami rozwojowymi oraz rozmiarami potencjału. Dominujące znaczenie ma Nokia, która dzięki podjęciu nowoczesnej produkcji, zwłaszcza telefonów komórkowych, obejmuje znaczną cześć światowego rynku na ten produkt. Firma ta poprzez posiadany kapitał, technologię oraz zasoby wiedzy jest bezkonkurencyjna na rynku europejskim, przez co osiaga najwyższe wyniki finansowe spośród badanych firm.

Siedziby zarządów korporacji informatycznych wykazują wyraźne tendencje do koncentracji przestrzennej na terenie krajów najbardziej rozwiniętych, tj. Francji i Wielkiej Brytanii, które wyróżniają się dużą chłonnością rynków wewnętrznych, stabilnością społeczną oraz 
polityczną, a także wysokim rozwojem technologicznym, stwarzając korporacjom dogodne warunki dalszego rozwoju. Istotne znaczenie w strukturze ma również Finlandia, reprezentowana przez jedną tylko korporację (Nokię), której wyniki działalności niejednokrotnie przewyższają wyniki grup korporacji z Francji czy Wielkiej Brytanii.

Wstępnie można przyjąć, że w zakresie lokalizacji i potencjału ekonomicznego firm informatycznych zaznaczają się tendencje do polaryzacji przestrzeni Unii Europejskiej, która nasila się także w zakresie nowoczesnej produkcji.

\section{Literatura}

1. Borowiec M., 2008, Rola szkolnictwa wyższego w procesie ksztaltowania gospodarki opartej na wiedzy [w:] Rola przedsiębiorczości w gospodarce opartej na wiedzy (red. Z. Zioło i T. Rachwał), „Przedsiębiorczość - Edukacja” nr 4, wydawnictwo Nowa Era i Zakład Przedsiębiorczości Instytutu Geografii Uniwersytetu Pedagogicznego w Krakowie, Warszawa-Kraków, s. 24-36.

2. Borowiec M., Dorocki S., Jenner B., Wpływ zasobów kapitału ludzkiego na kształtowanie społeczeństwa informacyjnego i innowacyjności struktur przemystowych [w:] Funkcje przemystu w ksztaltowaniu społeczeństwa informacyjnego / Functions of industry in the developing of an information society, red. Z. Zioło i T. Rachwał, „Prace Komisji Geografii Przemysłu PTG”, nr 13, Komisja Geografii Przemysłu PTG i Zakład Przedsiębiorczości i Gospodarki Przestrzennej Instytutu Geografii Uniwersytetu Pedagogicznego w Krakowie, Warszawa-Kraków, s. 95-109.

3. Dorocki S., 2008, Gospodarka oparta na wiedzy w założeniach strategii lizbońskiej na przykładzie Francji [w:] Rola przedsiębiorczości w gospodarce opartej na wiedzy (red. Z. Zioło i T. Rachwał), „Przedsiębiorczość - Edukacja” nr 4, wydawnictwo Nowa Era i Zakład Przedsiębiorczości Instytutu Geografii Uniwersytetu Pedagogicznego w Krakowie, Warszawa-Kraków, s. 176-184.

4. Kilar W., 2009, Koncentracja przestrzenna światowych firm informatycznych [w:] Wplyw procesów globalizacji i integracji europejskiej na transformację struktur przemysłowych (red. Z. Zioło i T. Rachwał), „Prace Komisji Geografii Przemysłu PTG”, nr 12, Komisja Geografii Przemysłu PTG i Zakład Przedsiębiorczości i Gospodarki Przestrzennej Instytutu Geografii Akademii Pedagogicznej w Krakowie, Warszawa-Kraków, s. 97-108.

5. Rachwał T., Wiederman K., Kilar T., 2009, Rola przemystu w gospodarce układów regionalnych Unii Europejskiej [w:] Problemy ksztaltowania sie przestrzennych struktur przemystowych $i$ ich otoczenia / Problems in the formation of industrial spatial structures and their surrounding, red. Z. Zioło i T. Rachwał, „Prace Komisji Geografii Przemysłu PTG”, nr 14, Komisja Geografii Przemysłu PTG i Zakład Przedsiębiorczości i Gospodarki Przestrzennej Instytutu Geografii Uniwersytetu Pedagogicznego w Krakowie, Warszawa-Kraków, s. 31-42.

6. Wajda E., 2006, Rozwój i struktura przestrzenna działalności Nokii w latach 1997-2003 [w:] Międzynarodowe uwarunkowania rozwoju przemystu, red. Z. Zioło i T. Rachwał, „Prace Komisji Geografii Przemysłu PTG”, nr 8, Komisja Geografii Przemysłu PTG w Warszawie i Zakład Przedsiębiorczości i Gospodarki Przestrzennej Instytutu Geografii Akademii Pedagogicznej w Krakowie, WarszawaKraków s. 219-240.

7. Zioło Z., 2004, Kształtowanie się firm informatycznych jako nowych elementów struktury przestrzennej przemystu [w:] Przemiany struktur przemystowych, red. Z. Zioło i Z. Makieła, „Prace Komisji Geografii Przemysłu PTG”, nr 7, Komisja Geografii Przemysłu PTG w Warszawie i Zakład Przedsiębiorczości Instytutu Geografii Akademii Pedagogicznej w Krakowie, Warszawa-Kraków, s. 97-106. 
8. Zioło Z., 2009, Rola przemystu w procesie ksztaltowania społeczeństwa informacyjnego [w:] Funkcje przemystu $w$ ksztaltowaniu społeczeństwa informacyjnego / Functions of industry in the developing of an information society, red. Z. Zioło i T. Rachwał, „Prace Komisji Geografii Przemysłu PTG”, nr 13, Komisja Geografii Przemysłu PTG i Zakład Przedsiębiorczości i Gospodarki Przestrzennej Instytutu Geografii Uniwersytetu Pedagogicznego w Krakowie, Warszawa-Kraków, s. 11-20.

9. Zimny Z., 2007, Rola korporacji transnarodowych (KTN) w rywalizacji i wspótpracy Unii Europejskiej $w$ świecie.

10. http://alcatel-lucent.com/

11. http://www.nokia.pl/

\section{Changes in the Potential of IT Corporations in the European Union: years 2004-2008}

The article presents a study of major IT corporations whose management authorities are based in EU member states. Its objective is to identify changes in the economic potential of the corporations in years 2004-2008 as well as factors which determine geographical distribution of IT corporations within the European Union. In order to prove the thesis and the objective, the following determining features have been used: changes in the potential of IT companies (number of companies, as well as the value of assets and market value), scope of company business operations (sales value), effectiveness of their operations (financial profit/loss figure) as well as correspondence between the type of operations and the performance of relevant corporations. 